\title{
To Save or Lose? A Cross-National Examination of the Disease Risk Framing Effect and its Cultural Correlates
}

\author{
Short title: Cross-National Disease Risk Framing \\ Hohjin $\operatorname{Im}^{* 1} \&$ Chuansheng Chen ${ }^{1}$ \\ ${ }^{1}$ University of California, Irvine
}

\begin{abstract}
Author Notes \& Biography.
Hohjin Im, Department of Psychological Science, University of California, Irvine. Email:

hohjini@uci.edu. Hohjin Im is currently a doctoral student at the Department of Psychological Science in University of California, Irvine researching cultural influences on decision-making and organizational behavior. *Corresponding Author

Chuansheng Chen, Chancellor's Professor, Department of Psychological Science, University of California, Irvine. Email: cschen@uci.edu. Chuansheng Chen is a Chancellor's Professor at the Department of Psychological Science in University of California, Irvine with diverse research interests ranging from cross-cultural psychology, adolescent development, cognitive neuroscience, and behavior genetics.
\end{abstract}

Acknowledgements.

The authors would like to thank the COVIDiSTRESS project team for making the data available for secondary analysis.

Disclosure of Interest.

The authors declare no conflict of interest. 


\title{
To Save or Lose? A Cross-National Examination of the Disease Risk Framing Effect and its Cultural Correlates
}

\begin{abstract}
Using a large dataset spanning 49 countries $(\mathrm{N}=102,830)$, we examined the robustness of Tversky and Kahneman's (1981) framing effect using a variation of the Asian Disease Scenario. Results indicated that the framing effect, in which respondents are more likely to take the riskaverse option (i.e., a known number of lives saved or lost) than the risky option (i.e., a probability of saving lives) when framed positively (as the number of lives saved) than negatively (as the number of lives lost), was replicated in $100 \%$ of the countries $\left(\mathrm{M}_{\text {Cohen's } h}=\right.$ 0.616). Country-level correlation analyses and multilevel mixed effects logistic modeling also indicated that societal values related to collectivism were associated with taking riskier options in both the positive and negative framing conditions. Collectivism was also significantly related to smaller framing effects. Implications and future directions are discussed.
\end{abstract}

Abstract word count: 139

Total word count (excluding Appendix): 6947

Keywords: Framing, disease scenario, risk, uncertainty, collectivism, culture 


\section{Introduction}

Tversky and Kahneman's (1981) seminal article questioning the field's overreliance on rationality as the framework with which humans engage in behavior remains highly influential to this day. In Tversky and Kahneman's (1981) first introduction of the Asian Disease Scenario, participants were led to decide whether they wished to ensure the safety of 200 lives at the expense of 400 or risk a 1/3 chance at saving all 600 lives and 2/3 chance at no one being saved. As one may see, the product of the probability and lives at stake in both options equal each other, rendering one's decision irrelevant in the grand scheme of things. Nonetheless, the prospect of guaranteed vs. gambling lives presents two different frames; the former option represents riskaversion and the latter risk-taking. Tversky and Kahneman (1981) found that when the participant's decisions were framed in a manner where the option pertained to saving lives (known as positive framing), $72 \%$ of participants opted for the guaranteed lives of 200 over gambling with the second option. On the other hand, when the participants' decisions were framed in a manner where the option pertained to determining how many people will die (known as negative framing), Tversky and Kahneman (1981) found that only $22 \%$ of participants opted for the guaranteed deaths of 400 (and subsequently saving the lives of 200). This finding that people generally prefer risk-averse routes of action when one stands to gain something (e.g., save lives) while being risk-taking when one stands to already lose something (e.g., lives lost) is termed the framing effect.

Numerous studies conducted in the past few decades have lent credence to the general robustness of the framing effect across its variants (e.g., Diederich et al., 2018; Druckman, 2001; Kühberger, 1998). Nevertheless, these studies have shown that much variation exists across situations and conditions. In a large meta-analysis of the framing effect from 136 studies, 
Kühberger (1998) reported that the framing effect may vary greatly across different research design choices, such as the outcome saliency and qualities of the risk involved. Further, Bless et al. (1998) reported that when the disease problem was presented as a statistical one, rather than a medical one, the large discrepancy between risk-aversion and risk-taking across the two framing conditions disappeared. The size of the risk-aversion bias may also be weakened when both frames (e.g., 200 lives are saved and 400 lives are lost) are made salient in one's determination of a preferred policy (Druckman, 2001).

However, there have been scant efforts for cross-national replication of the framing effect using the disease scenario, despite previous research implicating culture in risk preferences and management. Notably, cultural dimensions of collectivism and uncertainty avoidance have recently garnered attention from scholars in examining risk behaviors. For instance, individualism, the social valuation of the self as an immutable, independent agent (Hofstede, Hofstede, \& Minkov, 2010; Triandis, 2001), has been linked to risk taking behavior in financial (Ashraf, Zheng, \& Arshad, 2016; Breuer, Riesener, \& Salzmann, 2014; Kanagaretnam, Lim, \& Lobo, 2014) and corporate management (K. Li, Griffin, Yue, \& Zhao, 2013; Shao, Kwok, \& Zhang, 2013). Because of its emphasis on self-interests over group interests, individualism may promote risk-taking behavior for the benefit of the self (e.g., Shao et al., 2013). Under certain situations, however, collectivism may promote risk-taking because of the "cushion effect" (Weber, 1998), wherein individuals were afforded more opportunities to engage in risky behaviors as they perceived greater likelihood of receiving the aid from close others in the event that anything went wrong. In support of this theory, several studies have found that more collectivistic populations exhibited greater risk-seeking behaviors (Hsee \& Weber, 1999; S. Li, Bi, \& Zhang, 2009; Meisel, Ning, Campbell, \& Goodie, 2016; Weber, Hsee, \& Sokolowska, 
1998). However, these prior studies have examined the role of individualism-collectivism under the lens of business and financial dilemmas, in contrast to a public health dilemma, such as the disease scenario (Tversky \& Kahneman, 1981), where possible negative outcomes deal entirely with the livelihood of others with no direct, tangible consequence to the self. Given that prior studies have largely only examined cases in which outcomes would influence the self and close others, it remains difficult to propose a concrete hypothesis for the disease scenario in which the agent's decision imparts a unilateral decision for a mass of unknown others. Thus, we posit an exploratory proposition that collectivism will be related to the tendency for risk-aversion in the disease scenario but do not propose a specific direction of effect.

Similar to individualism-collectivism, more recent lines of research have examined the role of uncertainty avoidance in risk-taking behavior. Uncertainty avoidance refers to the degree to which societies prefer familiar events and outcomes over unknown ones (Hofstede, 2011; Hofstede et al., 2010). Although Hofstede et al. (2010) has generally maintained the position that uncertainty avoidance is not related to risk avoidance, the cultural dimension has nonetheless been shown through various studies to correlate with properties of risk-aversion in corporate policies (K. Li et al., 2013), firm behavior (Im \& Chen, 2020; Mihet, 2013), and banking (Ashraf et al., 2016; Kanagaretnam et al., 2014). Hence, some have proposed risk avoidance to be a subdimension within uncertainty avoidance due to overlapping conceptualization of the construct (Sharma, 2010). Although understudied relative to its individualism-collectivism counterpart, uncertainty avoidance may be a key underlying factor in risk management. Indeed, in a recent cross-national study on risk preferences, Rieger et al. (2015) found that across 53 countries, variations in risk attitudes and preferences were systematic in nature and could be explained in 
part by both individual and societal levels of uncertainty avoidance. Thus, we posit that uncertainty avoidance will be positively associated with risk-aversion in the disease scenario.

\section{The Current Study \& Analytical Plan}

The objectives of the current study included 1) replicating the framing effect from the Asian disease scenario cross-culturally and 2) exploring the cultural correlates of the tendencies for risk-aversion as well as susceptibility to the framing effect. We took advantage of the availability of a large multinational dataset, the COVIDiSTRESS project (Yamada et al., 2020), to examine the prevalence of the framing effect from the disease scenario amidst the COVID-19 pandemic across 49 countries. We used country-level statistics to explore the cultural values that correlated with the framing effect at the national level. Participant decisions were aggregated by each country to create a national-level index for the proportion of the country that were riskaverse under each frame. Bi-variate correlations were then run to examine the extent to which societal cultural indices related to the proportion of the population opting for the risk-averse decision under each framing condition as well as the country's susceptibility to the framing effect. As the sample size of available countries was small, more attention is given to the correlation coefficient size and pattern of results across different indices of national culture than strictly whether $p$-values reached statistical significance.

Cultural variables consistently related to the outcome variables across different measures of national indices were then entered as level 2 explanatory variables in a mixed-effects multilevel logistic regression model. Due to the large variation in sample size across countries (e.g., $\mathrm{n}=84$ for Afghanistan to $\mathrm{n}=19,934$ for Finland), the inclusion of the total sample into a multilevel mixed effects model would likely result in a biased estimation of level 2 variables on level 1 outcomes. To address this issue, down-sampling was conducted and a random subset of 
84 participants were selected from each country to match the size of the Afghanistan sample for a total reduced sample size of $n=4,116$ across 49 countries. Specific scripts, trimmed dataset, aggregated dataset, and data sources may be found online: [omitted].

\section{Methods}

\section{Sample}

All data and participants were gathered by an international group of researchers from the COVIDiSTRESS project (Yamada et al., 2020). A total of 173,426 participants were collected from 176 countries from March 30 to May 30 in 49 different languages and dialects. Initial cleaning conducted by COVIDiSTRESS using the inclusion criteria (e.g., 18+ years of age, informed consent) excluded 48,120 participants, yielding a total sample of 125,306 participants. For this study, the dataset was further reduced to meet specific criteria. While a total of 176 countries were collected, many countries reported very few participants (e.g., <10). This warranted elimination of countries without enough observations to maintain statistical power for subsequent analyses.

Slightly smaller proportion estimates for positive framing (i.e., 60\%) and negative framing (i.e., 30\%) than prior studies (e.g., Druckman, 2001; Tversky \& Kahneman, 1981) were used to conduct a more conservative a-priori power analysis. Given that framing effects have been shown to result in greater election of positively framed risk-aversive choices than negatively framed risk-aversive choices, we conducted a one-tail power analysis for two independent samples to achieve 0.90 statistical power. Power analysis recommended a minimum of 92 observations per group. To accommodate for possible missing data, countries with fewer than 100 participants or those not reporting any specific country of domicile were excluded from this study, dropping the total sample size to 122,882 and the number of countries to 49 . 
Lastly, participants who did not complete the framing disease scenario or those who reported prior knowledge of the measure were dropped, resulting in a final sample of 102,830 across 49 countries. After all exclusions, only Afghanistan (84 observations) and Russia (90 observations) fell below the designated minimum sample size. Post-hoc power analyses were conducted using sample proportions of the election of risk-averse choices (Table 2) to determine their statistical power. Both Russia (0.962) and Afghanistan (0.885) yielded good statistical power and remained in the final sample. Sample sizes and descriptive statistics by country are given in Table 1.

[Table 1]

\section{Measures}

\section{Disease Scenario}

Participants were given an adjusted version of the classic Asian Disease Scenario first used by Tversky and Kahneman (1981):

Imagine that [your country] is preparing for the outbreak of an unusual disease, which is expected to kill 600 people. Two alternative programs to combat the disease have been proposed. Assume that the exact scientific estimate of the consequences of the programs are as follows:

Which of the two programs would you favor?

In the positive framing condition, participants were given the option of selecting one of the following:

If Program A is adopted, 200 people will be saved. If Program B is adopted, there is $1 / 3$ probability that 600 people will be saved, and 2/3 probability that no people will be saved. 
In the negative framing condition, participants were given the option of selecting one of the following:

If Program C is adopted, 400 people will die.

If Program D is adopted, there is $1 / 3$ probability that nobody will die, and $2 / 3$ probability that 600 people will die.

\section{Societal Variables}

National levels of culture were derived from Hofstede's National Cultural Dimensions (2011; 2010) consisting of 1) Individualism-Collectivism, 2) Power Distance, 3) Uncertainty Avoidance, 4) Masculinity-Femininity, 5) Long-Term Orientation (i.e., FlexibilityMonumentalism; ), and 6) Indulgence-Restraint. In light of criticisms about Hofstede's cultural dimensions lacking surface validity (Blodgett, Bakir, \& Rose, 2008; House, Hanges, Javidan, Dorfman, \& Gupta, 2004), correlations were accompanied by neighboring indices of culture provided by GLOBE (House et al., 2004) and Schwartz (2008) for conceptual robustness checks. GLOBE's national cultural orientations (2004) consisted of practices and values for 1) Institutional Collectivism, 2) Ingroup Collectivism, 3) Power Distance, 4) Uncertainty Avoidance, 5) Humane Orientation, 6) Future Orientation, 7) Performance Orientation, 8) Gender Egalitarianism, and 9) Assertiveness. Schwartz's (2008) cultural value orientations consisted of 1) Harmony vs. Mastery, 2) Hierarchy vs. Egalitarianism, and 3) Embeddedness vs. Affective \& Intellectual Autonomy. While cultural variables associated with collectivism and uncertainty avoidance are hypothesized to be related to risk-aversion, all other cultural indices are included in this study for exploratory purposes. See supplemental materials for brief descriptions of each cultural dimension, orientation, or value and references for further detail.

\section{Demographic Variables}


Participants also provided key demographic variables of age, educational attainment, gender, and employment status. Educational attainment was measured via a seven-point scale (1 $=$ None, $2=$ Up to 6 years of school, $3=$ Up to 9 years of school, $4=$ Up to 12 years of school, 5 = Some College, short continuing education or equivalent, $6=$ College degree, bachelor, master, and $7=$ PhD/Doctorate . Gender was measured via selection of one of three identity categories $(1=$ Male, $2=$ Female , or $3=$ Other/would rather not say). Employment status was measured via selection of one of 6 employment categories $(1=$ Student, $2=$ Not employed, $3=$ Retired, $4=$ Part time employed, $5=$ Full time employed, or $6=$ Self-employed $)$. Those indicating student status, not employed, or retired were dummy coded as being unemployed while the rest were coded as being employed.

\section{Procedure}

Participants first provided informed consent for their participation in the study. Participants then provided demographic information before being randomly assigned to either the positive or the negative framing condition. Upon completing the measure, participants answered whether they had prior knowledge of the disease scenario. Following this measure, participants then completed other measures pertaining to COVID-19 (e.g., trust, concern, stress, personality, etc.) that were not examined in this article (refer to Yamada et al., 2020 for a complete list of variables in the dataset).

\section{Results}

\section{Descriptive Comparisons}

[Table 2]

Across all countries, positive framing resulted in a higher proportion of individuals opting for the risk-averse option than did negative framing ( $p$ ranging from 0.024 to $<0.001$; 
Table 2). Cohen's $h$ effect sizes were relatively large across all countries ranging from 0.338 to 1.095, averaging 0.616. Possible gender differences were also explored. In the positive framing condition, males $(\mathrm{n}=13,596, \mathrm{M}=0.654)$ were less likely to opt for the risk-averse option than were females $(n=37,292, M=0.670), z=-3.386, p=0.001$. However, in the negative framing condition, there were no differences between males $(n=13,487, M=0.366)$ and females $(n=$ $37,109, \mathrm{M}=0.362), \mathrm{z}=0.827, p=0.407$. At the country-level, risk-aversion was significantly correlated between the two framing conditions, $r=0.360, p=0.011$.

\section{Correlation Analyses}

\section{[Table 3]}

To examine the cultural correlates of the tendency for risk-aversion and susceptibility to the framing effect, societal-level correlations were conducted (Table 3). Although the cultural indices pertaining to individualism-collectivism and uncertainty avoidance were of main foci, all cultural dimensions were examined for exploratory purposes. For Hofstede's cultural dimensions, indulgence-restraint was a positive correlate of positive and negative framing while collectivism and power distance were strong negative correlates of negative framing. While not significant at the 0.05 level, collectivism and power distance also showed notable $r$ coefficients in the negative direction. Collectivism, and power distance remained significantly correlated with the size of the framing effect.

For GLOBE's cultural practices, ingroup collectivism was strongly and negatively correlated with opting for the risk-aversive option while uncertainty avoidance went the opposite direction. Institutional collectivism showed a notable positive correlation coefficient for riskaversion for the positive framing condition and framing effect size. Power distance yielded a significant negative correlation with opting for the risk-aversive option for the negative framing 
condition whereas performance orientation went the opposite direction. Future orientation also yielded notable positive coefficients for risk-aversion for both framing conditions. For cultural values, institutional collectivism yielded notable negative correlation coefficients with framing effect size and proportion of participants opting for risk-aversion under the positive framing condition. Ingroup collectivism, performance orientation, and gender egalitarianism, on the other hand, yielded notable positive correlations with framing effect size. Gender egalitarianism yielded a notable positive correlation for risk aversion under the positive framing condition whereas future orientation yielded a notable negative correlation under the negative framing condition. Lastly, uncertainty avoidance yielded significant negative correlations with riskaversion under both framing conditions.

For positive framing, egalitarianism, affective autonomy, and intellectual autonomy were strong positive correlates while hierarchy and embeddedness were moderate to strong negative correlates. For negative framing, affective autonomy remained a significant positive correlate. While not significant at the 0.05 level, hierarchy, egalitarianism, embeddedness, and intellectual autonomy showed notable $r$ coefficients in the same direction as with positive framing. Embeddedness was negatively correlated with the size of the framing effect while egalitarianism, affective autonomy, and intellectual autonomy showed notable $r$ coefficients in the positive direction. Across all cultural indices, measures related to collectivism were consistent correlates of risk-aversion and are depicted in Figures 1-2.

[Figure 1]

[Figure 2]

\section{Mixed-Effects Logistic Modeling}

[Table 4] 
Upon examining cultural correlates at the societal level, individualism-collectivism was the only consistent correlate across all cultural indices. Thus, individualism-collectivism was further examined at the individual level using mixed-effects logistic modeling (Table 4). Across all models, those who received the negative framing condition were approximately 4 times less likely to opt for the risk-averse choice while females, compared to males, were about 18-35\% more likely to opt for the risk-averse choice $(p=0.001-0.034)$. In the Hofstede model, participants from more collectivistic cultures were approximately 1.22 times less likely to opt for the risk-averse choice $(p<0.001)$. A similar pattern was observed for ingroup collectivism practices $(p=0.002)$ and institutional collectivism values $(p=0.020)$. Lastly, a relatively similar effect size was observed in the same direction for cultural embeddedness $(p=0.002)$. These effects were generally robust even after controlling for other cultural indices (see Appendix).

Although the effect of uncertainty avoidance on risk aversion was not robust for Hofstede's measurement, there were strong correlations with GLOBE's uncertainty avoidance practice and value on risk-aversion. Thus, a mixed-effects multilevel logistic regression was conducted and found that uncertainty avoidance practice $(\mathrm{OR}=1.247,95 \%$ CI $[1.043,1.490], p$ $=0.016)$ and value $(\mathrm{OR}=0.775,95 \% \mathrm{CI}[0.642,0.936], p=0.008)$ were significant correlates, controlling for demographics and framing condition. Participants from cultures practicing high uncertainty avoidance were approximately 1.25 times more likely to opt for the risk-averse choice whereas those from cultures valuing high uncertainty avoidance were approximately 0.78 times as likely. However, these effects were generally not robust when controlling for other cultural indices (see Appendix).

\section{Discussion}


Across all countries, the positive vs. negative framing effect in risk management decision making was robust and strong with Cohen's $h$ effect sizes ranging from 0.338 at the smallest to 1.095 at the largest for an average of 0.616 . The global average proportion was noticeably smaller for the positive framing condition and larger for the negative framing condition than the findings originally reported in Tversky and Kahneman (1981) as well as subsequent studies (e.g., Druckman, 2001). Nonetheless, the US and Canadian samples show remarkedly similar results to these prior studies where samples were originally collected, suggesting that even under the social ecological context of the ongoing COVID-19 pandemic, participants' response to the disease scenario may not yield much deviation from the original findings. The framing effect successfully replicated for $100 \%$ of the countries examined. However, the large range of the effect sizes suggested significant and noteworthy variations across countries.

Specifically, subsequent correlations at the aggregated country level revealed that societies higher on collectivism (e.g., Hofstede's collectivism, GLOBE's ingroup collectivism, and Schwartz's embeddedness) were more risk-taking in both the positive and negative framing conditions, albeit the relation for positive framing appeared much larger than under negative framing. Similarly, we observed the inverse relation for Schwartz's autonomy measures, which are conceptualized as being the opposing values of embeddedness. Subsequently, correlation results provided some evidence that collectivism was associated with smaller framing effects. Mixed-effects logistic regression results further supported the claim that those from more collectivistic cultures were approximately $15-22 \%$ more likely than their individualistic counterparts to engage in the risky program, even after controlling for the framing condition. This is in contrast to the body of literature evidencing the link between individualism and risky tendencies (e.g., Ashraf et al., 2016; Breuer et al., 2014; Mihet, 2013; Shao et al., 2013) while 
supporting another body of literature linking collectivism with risk-seeking (e.g., Hsee \& Weber, 1999; Weber et al., 1998).

One possible explanation may be that the disease scenario entirely concerns the wellbeing of others from a third-party perspective. In other words, in prior studies of individualismcollectivism and risk, the possible harm stemming from the risky behavior often also befalls oneself, such as in managing one's finances, rather than solely others like in the disease scenario. Indeed, for collectivistic cultures, an agent may be more motivated to engage in riskier options to maximize the potential well-being of the greater mass out of a perceived social obligation to do so even at the expense of one's own conscious guilt in the event that no one is saved. This is in contrast with individualistic cultures were the risk-averse option to guarantee the lives of a smaller mass and possibly minimize said guilt from the possible likelihood of mass death may be the more palatable option.

This rationalization may partly also explain the tendency for collectivistic cultures to show less susceptibility to the framing effect in general than their individualistic counterparts. Indeed, when risky options were preceded by context relevant to the self, susceptibility to the framing effect diminished as participants confronted the Asian disease problem more analytically (McElroy \& Seta, 2003). According to this premise, the impending danger of the disease to fellow country inhabitants may have induced a greater sense of relevance among participants from collectivistic societies due to the cultural doctrine emphasizing greater concern for the collective well-being. Thus, participants from these cultures may have approached the Asian disease problem more analytically than those from individualistic cultures. However, such conjectures need to be tested in future research to better understand the mechanisms underlying the relation between collectivism and the framing effect. 
Results also indicated that Hofstede's power distance index yielded similar relations as collectivism. This is not surprising given the high correlation between collectivism and power distance. Interpretation of power distance, however, is less clear as both GLOBE's power distance and Schwartz's hierarchy indices produced much smaller effects, some nonsignificant. Further, in light of recent propositions that Hofstede's power distance is a natural branch of individualism-collectivism (Minkov, 2018), the higher effect size may partly stem from overlapping latent conceptualization. Further research is needed to explore any underlying connections between power distance and risk management.

Another interesting cultural dimension that warrants further inquiry is uncertainty avoidance. Although Hofstede et al. (2010) maintains that uncertainty avoidance is not associated with risk avoidance, the dimension has nonetheless been correlated with risk management in past research (e.g., K. Li et al., 2013). In Rieger et al.’s (2015) study, uncertainty avoidance was positively associated with greater risk-aversion in gains and greater risk-seeking in losses. However, the role of uncertainty avoidance in risk-aversion under different framing conditions is unclear from the results of this study due to the lack of clear pattern of significant effects across different indices. Nonetheless, correlations and multilevel logistic regression results did indicate that GLOBE cultural practices and values in uncertainty avoidance were positively and negatively related to risk-aversion, respectively. The opposing direction of effects between practices and values is not surprising, as cultural practices and values generally tend to be negatively correlated (House et al., 2004). The lack of consistent results across indices may in part be due to the way in which Hofstede's and GLOBE's measurements of uncertainty avoidance deviate greatly in their surface validity (Hofstede et al., 2010; House et al., 2004). 
Given that GLOBE's measurement of uncertainty avoidance has more surface validity, the possible relation may be worth investigating further.

At the individual level, using the entire sample, we found a significant but negligible gender difference under the positive framing condition and no gender difference under the negative framing condition, consistent prior evidence of no gender differences in the framing effect (e.g., Druckman, 2001). However, results from the mixed effects logistic model suggest that gender differences may manifest when controlling for external factors. Specifically, females tended to be more risk-averse in models where culture was accounted for. This is partly in line with the general trend for females to be more risk-averse than males (e.g., Byrnes et al., 1999), especially when the outcome is framed in gains (Rieger et al., 2015). Future research should examine the role of culture in gender differences in risk management.

\section{Limitations}

Several limitations should be considered. First, data from COVIDiSTRESS were not collected from nationally representative samples. Second, because sample sizes varied widely by country, countries with smaller sample sizes were more likely to have a greater margin of error. Third, the measures of cultural indices are not without faults. Hofstede's Cultural Dimensions have come under scrutiny regarding questionable surface validity (Blodgett et al., 2008; House et al., 2004) and most recently construct validity (Minkov, 2018). GLOBE's Cultural Orientations, on the other hand, have come under scrutiny regarding conceptually ambiguous items and negative correlation between practices and values (Brewer \& Venaik, 2010; Hofstede, 2010; Maseland \& van Hoorn, 2009). Schwartz's Cultural Values lack proper representation of their populations because the national values were derived from predominately teacher samples (Schwartz, 2008). Due to these shortcomings, we reported correlations of all available cultural 
indices for conceptual robustness across multiple measures of similar constructs. Nonetheless, the results of this study may benefit from replication attempts with more validated measures of cultural values. Finally, although COVIDiSTRESS reached a wide audience across the globe, the number of countries included in the current study was limited for country-level analyses because approximately $50 \%$ of countries had missing data for one of the indices of cultural dimensions, orientations, and values. Thus, caution is recommended when inferring the generalizability of the results reported in this article. In particular,

\section{Conclusion}

This study provides an empirical, cross-national replication of Tversky and Kahneman's (1981) Asian Disease Scenario. Across the 49 different countries examined, the framing effect for the disease scenario replicated in every society examined. This study not only adds to the growing body of literature showing the robustness of the framing effect (and, more broadly,

prospect theory) cross-nationally (e.g., Rieger et al., 2015; Ruggeri et al., 2020), but also advocates for the consideration of culture in decision making. An understanding of cultural factors in decision making should be integrated into classical theories of decision making.

\section{References}

Ashraf, B. N., Zheng, C., \& Arshad, S. (2016). Effects of national culture on bank risk-taking behavior. Research in International Business and Finance, 37, 309-326. https://doi.org/10.1016/j.ribaf.2016.01.015

Bless, H., Betsch, T., \& Franzen, A. (1998). Framing the framing effect: The impact of context cues on solutions to the 'Asian disease' problem. European Journal of Social Psychology, 28(2), 287-291. https://doi.org/10.1002/(SICI)10990992(199803/04)28:2<287::AID-EJSP861>3.0.CO;2-U 
Blodgett, J. G., Bakir, A., \& Rose, G. M. (2008). A test of the validity of Hofstede's cultural framework. Journal of Consumer Marketing, 25(6), 339-349. https://doi.org/10.1108/07363760810902477

Breuer, W., Riesener, M., \& Salzmann, A. J. (2014). Risk aversion vs. individualism: What drives risk taking in household finance? The European Journal of Finance, 20(5), 446462. https://doi.org/10.1080/1351847X.2012.714792

Brewer, P., \& Venaik, S. (2010). GLOBE practices and values: A case of diminishing marginal utility? Journal of International Business Studies, 41(8), 1316-1324. https://doi.org/10.1057/jibs.2010.23

Byrnes, J. P., Miller, D. C., \& Schafer, W. D. (1999). Gender Differences in Risk Taking: A Meta-Analysis. Psychological Bulletin, 125(3), 367-383. https://doi.org/10.1037/00332909.125.3.367

Diederich, A., Wyszynski, M., \& Ritov, I. (2018). Moderators of framing effects in variations of the Asian Disease problem: Time constraint, need, and disease type. Judgment and Decision Making, 13(6), 529-546.

Druckman, J. N. (2001). Evaluating framing effects. Journal of Economic Psychology, 22(1), 11. https://doi.org/10.1016/S0167-4870(00)00032-5

Hofstede, G. (2010). The GLOBE debate: Back to relevance. Journal of International Business Studies, 41(8), 1339-1346. https://doi.org/10.1057/jibs.2010.31

Hofstede, G. (2011). Dimensionalizing Cultures: The Hofstede Model in Context. Online Readings in Psychology and Culture, 2(1). https://doi.org/10.9707/2307-0919.1014

Hofstede, G., Hofstede, G. J., \& Minkov, M. (2010). Cultures and Organizations: Software of the Mind, Third Edition. McGraw Hill Professional. 
House, R. J., Hanges, P. J., Javidan, M., Dorfman, P. W., \& Gupta, V. (Eds.). (2004). Culture, Leadership, and Organizations: The GLOBE Study of 62 Societies (1 edition). Thousand Oaks, Calif: SAGE Publications, Inc.

Hsee, C. K., \& Weber, E. U. (1999). Cross-national differences in risk preference and lay predictions. Journal of Behavioral Decision Making, 12(2), 165-179. https://doi.org/10.1002/(SICI)1099-0771(199906)12:2<165::AID-BDM316>3.0.CO;2-N

Im, H., \& Chen, C. (2020). Cultural dimensions as correlates of favoritism and the mediating role of trust. Cross Cultural \& Strategic Management, 27(3), 417-445. https://doi.org/10.1108/CCSM-09-2019-0165

Kanagaretnam, K., Lim, C. Y., \& Lobo, G. J. (2014). Influence of National Culture on Accounting Conservatism and Risk-Taking in the Banking Industry. The Accounting Review, 89(3), 1115-1149. https://doi.org/10.2308/accr-50682

Kühberger, A. (1998). The Influence of Framing on Risky Decisions: A Meta-analysis. Organizational Behavior and Human Decision Processes, 75(1), 23-55. https://doi.org/10.1006/obhd.1998.2781

Li, K., Griffin, D., Yue, H., \& Zhao, L. (2013). How does culture influence corporate risktaking? Journal of Corporate Finance, 23, 1-22. https://doi.org/10.1016/j.jcorpfin.2013.07.008

Li, S., Bi, Y.-L., \& Zhang, Y. (2009). Asian Risk Seeking and Overconfidence. Journal of Applied Social Psychology, 39(11), 2706-2736. https://doi.org/10.1111/j.15591816.2009.00545.x 
Maseland, R., \& van Hoorn, A. (2009). Explaining the negative correlation between values and practices: A note on the Hofstede-GLOBE debate. Journal of International Business Studies, 40(3), 527-532. https://doi.org/10.1057/jibs.2008.68

McElroy, T., \& Seta, J. J. (2003). Framing effects: An analytic-holistic perspective. Journal of Experimental Social Psychology, 39(6), 610-617. https://doi.org/10.1016/S00221031(03)00036-2

Meisel, M. K., Ning, H., Campbell, W. K., \& Goodie, A. S. (2016). Narcissism, Overconfidence, and Risk Taking in U.S. and Chinese Student Samples. Journal of Cross-Cultural Psychology, 47(3), 385-400. https://doi.org/10.1177/0022022115621968

Mihet, R. (2013). Effects of culture on firm risk-taking: A cross-country and cross-industry analysis. Journal of Cultural Economics, 37(1), 109-151. https://doi.org/10.1007/s10824012-9186-2

Minkov, M. (2018). A revision of Hofstede's model of national culture: Old evidence and new data from 56 countries. Cross Cultural \& Strategic Management, 25(2), 231-256. https://doi.org/10.1108/CCSM-03-2017-0033

Rieger, M. O., Wang, M., \& Hens, T. (2015). Risk Preferences Around the World. Management Science, 61(3), 637-648. https://doi.org/10.1287/mnsc.2013.1869

Ruggeri, K., Alí, S., Berge, M. L., Bertoldo, G., Bjørndal, L. D., Cortijos-Bernabeu, A., ... Folke, T. (2020). Replicating patterns of prospect theory for decision under risk. Nature Human Behaviour, 4(6), 622-633. https://doi.org/10.1038/s41562-020-0886-X

Schwartz, S. (2008). The 7 Schwartz cultural value orientation scores for 80 countries. https://doi.org/10.13140/RG.2.1.3313.3040 
Shao, L., Kwok, C. C. Y., \& Zhang, R. (2013). National culture and corporate investment. Journal of International Business Studies, 44(7), 745-763. https://doi.org/10.1057/jibs.2013.26

Sharma, P. (2010). Measuring personal cultural orientations: Scale development and validation. Journal of the Academy of Marketing Science, 38(6), 787-806. https://doi.org/10.1007/s11747-009-0184-7

Triandis, H. C. (2001). Individualism-Collectivism and Personality. Journal of Personality, 69(6), 907-924. https://doi.org/10.1111/1467-6494.696169

Tversky, A., \& Kahneman, D. (1981). The framing of decisions and the psychology of choice. Science, 211(4481), 453-458. https://doi.org/10.1126/science.7455683

Weber, E. U., Hsee, C. K., \& Sokolowska, J. (1998). What Folklore Tells Us about Risk and Risk Taking: Cross-Cultural Comparisons of American, German, and Chinese Proverbs. Organizational Behavior and Human Decision Processes, 75(2), 170-186. https://doi.org/10.1006/obhd.1998.2788

Yamada, Y., Ćepulić, D.-B., Coll-Martín, T., Debove, S., Gautreau, G., Han, H., ... Lieberoth, A. (2020). COVIDiSTRESS Global Survey dataset on psychological and behavioural consequences of the COVID-19 outbreak [Preprint]. PsyArXiv. https://doi.org/10.31234/osf.io/v7cep 
Table 1. Country-level and Global Descriptive Statistics

\begin{tabular}{|c|c|c|c|c|c|c|c|}
\hline \multirow[b]{2}{*}{ Country } & \multicolumn{2}{|c|}{ Age } & \multicolumn{2}{|c|}{ Education } & \multirow{2}{*}{$\frac{\text { Female \% }}{M}$} & \multirow{2}{*}{$\frac{\text { Employed \% }}{\mathrm{M}}$} & \multirow{2}{*}{$\frac{\text { Sample }}{\mathrm{N}}$} \\
\hline & $\mathbf{M}$ & SD & $\mathbf{M}$ & SD & & & \\
\hline Afghanistan & 29.07 & 12.33 & 5.34 & 0.98 & 0.49 & 0.52 & 84 \\
\hline Argentina & 40.25 & 14.99 & 5.26 & 1.00 & 0.84 & 0.57 & 4849 \\
\hline Australia & 42.80 & 14.17 & 5.76 & 0.88 & 0.76 & 0.68 & 262 \\
\hline Austria & 38.39 & 11.42 & 5.83 & 0.81 & 0.71 & 0.75 & 259 \\
\hline Bangladesh & 28.05 & 6.31 & 5.87 & 0.64 & 0.48 & 0.55 & 239 \\
\hline Belgium & 36.26 & 12.61 & 5.57 & 0.90 & 0.57 & 0.66 & 531 \\
\hline Bosnia and Herzegovina & 36.17 & 11.37 & 5.54 & 0.83 & 0.74 & 0.69 & 1044 \\
\hline Brazil & 33.95 & 12.99 & 5.68 & 0.72 & 0.74 & 0.60 & 606 \\
\hline Bulgaria & 40.87 & 13.30 & 5.61 & 0.78 & 0.81 & 0.33 & 3661 \\
\hline Canada & 41.03 & 14.01 & 5.75 & 0.88 & 0.68 & 0.65 & 395 \\
\hline Colombia & 33.35 & 12.23 & 5.93 & 0.60 & 0.61 & 0.69 & 174 \\
\hline Croatia & 34.71 & 11.70 & 5.52 & 0.87 & 0.78 & 0.69 & 2465 \\
\hline Czech Republic & 32.89 & 11.24 & 5.42 & 0.87 & 0.79 & 0.72 & 1707 \\
\hline Denmark & 41.86 & 14.00 & 5.24 & 0.88 & 0.79 & 0.69 & 9280 \\
\hline Finland & 42.44 & 13.85 & 5.10 & 1.37 & 0.83 & 0.68 & 19934 \\
\hline France & 32.77 & 12.38 & 5.61 & 0.97 & 0.52 & 0.62 & 11516 \\
\hline Germany & 36.41 & 11.79 & 5.66 & 0.86 & 0.69 & 0.71 & 1189 \\
\hline Greece & 41.08 & 11.61 & 5.80 & 0.88 & 0.77 & 0.76 & 538 \\
\hline Hungary & 46.96 & 15.03 & 5.04 & 0.95 & 0.68 & 0.69 & 1041 \\
\hline Indonesia & 30.31 & 9.04 & 5.75 & 0.68 & 0.69 & 0.85 & 1261 \\
\hline Ireland & 39.59 & 10.15 & 5.57 & 0.75 & 0.82 & 0.75 & 175 \\
\hline Italy & 44.48 & 15.05 & 5.28 & 1.13 & 0.77 & 0.64 & 1317 \\
\hline Japan & 44.32 & 11.25 & 4.90 & 1.50 & 0.46 & 0.77 & 4551 \\
\hline Korea, South & 37.95 & 10.34 & 6.08 & 0.73 & 0.50 & 0.70 & 401 \\
\hline Kosovo & 27.50 & 8.65 & 5.08 & 0.73 & 0.64 & 0.58 & 1727 \\
\hline Lithuania & 38.06 & 12.20 & 5.84 & 0.56 & 0.75 & 0.83 & 7103 \\
\hline Malaysia & 36.56 & 14.26 & 6.17 & 0.66 & 0.76 & 0.58 & 450 \\
\hline Mexico & 36.64 & 13.45 & 6.06 & 0.86 & 0.73 & 0.69 & 8024 \\
\hline Netherlands & 44.39 & 14.51 & 5.88 & 0.54 & 0.76 & 0.72 & 1165 \\
\hline New Zealand & 40.61 & 12.66 & 5.72 & 0.73 & 0.88 & 0.82 & 103 \\
\hline Norway & 39.67 & 11.30 & 5.75 & 0.74 & 0.72 & 0.81 & 141 \\
\hline Pakistan & 26.44 & 7.96 & 5.81 & 0.67 & 0.69 & 0.34 & 239 \\
\hline Panama & 38.23 & 14.39 & 6.20 & 0.92 & 0.75 & 0.60 & 590 \\
\hline Philippines & 25.35 & 10.90 & 5.30 & 0.75 & 0.67 & 0.50 & 428 \\
\hline Poland & 31.13 & 7.52 & 5.48 & 0.88 & 0.88 & 0.72 & 2544 \\
\hline Portugal & 33.30 & 12.92 & 5.22 & 0.97 & 0.86 & 0.59 & 841 \\
\hline Romania & 33.74 & 9.19 & 5.80 & 0.75 & 0.74 & 0.86 & 203 \\
\hline Russia & 32.27 & 12.08 & 5.82 & 0.95 & 0.66 & 0.58 & 90 \\
\hline Serbia & 37.89 & 12.06 & 5.40 & 0.83 & 0.68 & 0.74 & 196 \\
\hline Slovakia & 41.43 & 12.83 & 5.63 & 0.98 & 0.76 & 0.79 & 784 \\
\hline South Africa & 40.91 & 10.57 & 5.76 & 0.71 & 0.74 & 0.87 & 100 \\
\hline Spain & 37.72 & 14.87 & 5.33 & 1.14 & 0.69 & 0.62 & 526 \\
\hline Sweden & 45.84 & 12.11 & 5.49 & 0.94 & 0.76 & 0.81 & 2543 \\
\hline Switzerland & 42.67 & 17.27 & 5.55 & 0.97 & 0.62 & 0.63 & 980 \\
\hline Taiwan & 32.88 & 10.97 & 6.15 & 0.71 & 0.73 & 0.68 & 2282 \\
\hline Turkey & 33.16 & 11.55 & 6.14 & 0.82 & 0.76 & 0.58 & 989 \\
\hline United Kingdom & 39.46 & 12.73 & 5.79 & 0.77 & 0.77 & 0.72 & 1226 \\
\hline United States & 42.71 & 14.70 & 5.94 & 0.74 & 0.77 & 0.68 & 1932 \\
\hline Vietnam & 25.51 & 7.46 & 5.45 & 0.99 & 0.72 & 0.58 & 145 \\
\hline
\end{tabular}


Table 2. Proportion of Risk-Aversion and Effect Sizes in Comparison of Framing Effects Across Countries

\begin{tabular}{|c|c|c|c|c|c|c|c|}
\hline Country & Pos. N & Pos. \% & Neg. $N$ & Neg. \% & $z$ & $p$ & $\boldsymbol{h}$ \\
\hline Afghanistan & 39 & 0.615 & 45 & 0.311 & 2.792 & 0.003 & 0.620 \\
\hline Argentina & 2431 & 0.596 & 2418 & 0.360 & 16.449 & $<0.001$ & 0.477 \\
\hline Australia & 131 & 0.710 & 131 & 0.282 & 6.928 & $<0.001$ & 0.885 \\
\hline Austria & 125 & 0.656 & 134 & 0.284 & 5.999 & $<0.001$ & 0.764 \\
\hline Bangladesh & 115 & 0.600 & 124 & 0.250 & 5.480 & $<0.001$ & 0.725 \\
\hline Belgium & 263 & 0.665 & 268 & 0.440 & 5.213 & $<0.001$ & 0.457 \\
\hline Bosnia and Herzegovina & 539 & 0.590 & 505 & 0.352 & 7.695 & $<0.001$ & 0.481 \\
\hline Brazil & 305 & 0.630 & 301 & 0.319 & 7.665 & $<0.001$ & 0.633 \\
\hline Bulgaria & 1851 & 0.609 & 1810 & 0.298 & 18.891 & $<0.001$ & 0.636 \\
\hline Canada & 200 & 0.675 & 195 & 0.364 & 6.186 & $<0.001$ & 0.633 \\
\hline Colombia & 87 & 0.552 & 87 & 0.356 & 2.596 & 0.005 & 0.396 \\
\hline Croatia & 1210 & 0.624 & 1255 & 0.330 & 14.614 & $<0.001$ & 0.598 \\
\hline Czech Republic & 846 & 0.537 & 861 & 0.347 & 7.905 & $<0.001$ & 0.385 \\
\hline Denmark & 4639 & 0.685 & 4641 & 0.370 & 30.391 & $<0.001$ & 0.642 \\
\hline Finland & 10004 & 0.748 & 9930 & 0.406 & 48.881 & $<0.001$ & 0.708 \\
\hline France & 5852 & 0.714 & 5664 & 0.434 & 30.400 & $<0.001$ & 0.575 \\
\hline Germany & 604 & 0.619 & 585 & 0.296 & 11.172 & $<0.001$ & 0.661 \\
\hline Greece & 277 & 0.671 & 261 & 0.372 & 6.942 & $<0.001$ & 0.608 \\
\hline Hungary & 514 & 0.646 & 527 & 0.323 & 10.427 & $<0.001$ & 0.658 \\
\hline Indonesia & 637 & 0.509 & 624 & 0.330 & 6.438 & $<0.001$ & 0.365 \\
\hline Ireland & 76 & 0.658 & 99 & 0.333 & 4.268 & $<0.001$ & 0.662 \\
\hline Italy & 658 & 0.573 & 659 & 0.284 & 10.598 & $<0.001$ & 0.593 \\
\hline Japan & 2298 & 0.754 & 2253 & 0.338 & 28.193 & $<0.001$ & 0.863 \\
\hline Korea, South & 203 & 0.655 & 198 & 0.343 & 6.247 & $<0.001$ & 0.635 \\
\hline Kosovo & 860 & 0.638 & 867 & 0.355 & 11.761 & $<0.001$ & 0.574 \\
\hline Lithuania & 3528 & 0.629 & 3575 & 0.296 & 28.147 & $<0.001$ & 0.681 \\
\hline Malaysia & 220 & 0.568 & 230 & 0.400 & 3.565 & $<0.001$ & 0.338 \\
\hline Mexico & 4078 & 0.594 & 3946 & 0.371 & 19.983 & $<0.001$ & 0.450 \\
\hline Netherlands & 550 & 0.662 & 615 & 0.431 & 7.897 & $<0.001$ & 0.468 \\
\hline New Zealand & 57 & 0.825 & 46 & 0.391 & 4.538 & $<0.001$ & 0.927 \\
\hline Norway & 70 & 0.800 & 71 & 0.282 & 6.170 & $<0.001$ & 1.095 \\
\hline Pakistan & 126 & 0.603 & 113 & 0.363 & 3.706 & $<0.001$ & 0.485 \\
\hline Panama & 301 & 0.615 & 289 & 0.394 & 5.367 & $<0.001$ & 0.446 \\
\hline Philippines & 216 & 0.611 & 212 & 0.231 & 7.956 & $<0.001$ & 0.792 \\
\hline Poland & 1276 & 0.606 & 1268 & 0.228 & 19.331 & $<0.001$ & 0.789 \\
\hline Portugal & 416 & 0.680 & 425 & 0.289 & 11.345 & $<0.001$ & 0.804 \\
\hline Romania & 107 & 0.561 & 96 & 0.292 & 3.861 & $<0.001$ & 0.551 \\
\hline Russia & 46 & 0.543 & 44 & 0.205 & 3.306 & $<0.001$ & 0.717 \\
\hline Serbia & 107 & 0.542 & 89 & 0.326 & 3.030 & 0.001 & 0.440 \\
\hline Slovakia & 385 & 0.647 & 399 & 0.353 & 8.231 & $<0.001$ & 0.597 \\
\hline South Africa & 49 & 0.571 & 51 & 0.373 & 1.983 & 0.024 & 0.399 \\
\hline Spain & 263 & 0.681 & 263 & 0.346 & 7.686 & $<0.001$ & 0.684 \\
\hline Sweden & 1295 & 0.697 & 1248 & 0.386 & 15.743 & $<0.001$ & 0.635 \\
\hline Switzerland & 491 & 0.688 & 489 & 0.444 & 7.706 & $<0.001$ & 0.498 \\
\hline Taiwan & 1098 & 0.501 & 1184 & 0.316 & 8.995 & $<0.001$ & 0.379 \\
\hline Turkey & 475 & 0.585 & 514 & 0.239 & 11.072 & $<0.001$ & 0.720 \\
\hline United Kingdom & 646 & 0.692 & 580 & 0.378 & 11.020 & $<0.001$ & 0.641 \\
\hline United States & 939 & 0.703 & 993 & 0.378 & 14.316 & $<0.001$ & 0.665 \\
\hline Vietnam & 74 & 0.514 & 71 & 0.239 & 3.412 & $<0.001$ & 0.577 \\
\hline
\end{tabular}


Descriptive Statistics

\begin{tabular}{lcccrrrr} 
Minimum & 39 & 0.501 & 44 & 0.205 & 1.983 & $<0.001$ & 0.338 \\
Maximum & 10004 & 0.825 & 9930 & 0.444 & 48.881 & 0.024 & 1.095 \\
Average & 1052.59 & 0.634 & 1045.98 & 0.335 & 10.867 & 0.001 & 0.612 \\
Standard Deviation & 1792.96 & 0.070 & 1771.19 & 0.057 & 9.080 & 0.003 & 0.156 \\
\hline
\end{tabular}

Note: Pos.N = Sample size for positive frame condition; Neg.N = Sample size for negative frame condition; Pos. $\%=$ Proportion of sample choosing risk-averse option; Neg. $\%=$ Proportion of sample choosing risk-averse option; $h=$ Cohen's h effect size 
Table 3. Cultural Correlates of Risk-Aversion Effect Under Positive and Negative Framing

\begin{tabular}{|c|c|c|c|c|c|c|}
\hline \multirow[b]{2}{*}{ Variables } & \multicolumn{2}{|c|}{ Positive Framing } & \multicolumn{2}{|c|}{ Negative Framing } & \multicolumn{2}{|c|}{ Cohen's $h$} \\
\hline & $r$ & $p$ & $\boldsymbol{r}$ & $p$ & $r$ & $p$ \\
\hline \multicolumn{7}{|c|}{ Hofstede Cultural Dimensions } \\
\hline Collectivism & $-0.605 * * *$ & $<.001$ & $-0.272 \dagger$ & 0.065 & $-0.364^{*}$ & 0.012 \\
\hline Power Distance & $-0.577 * * *$ & $<.001$ & $-0.221 \dagger$ & 0.135 & $-0.375^{*}$ & 0.009 \\
\hline Uncertainty Avoidance & -0.174 & 0.243 & -0.136 & 0.364 & -0.066 & 0.660 \\
\hline Masculinity & -0.062 & 0.677 & -0.031 & 0.834 & -0.043 & 0.773 \\
\hline Long-Term Orientation & -0.169 & 0.261 & 0.012 & 0.935 & -0.174 & 0.246 \\
\hline Indulgence-Restraint & $0.364 *$ & 0.013 & $0.485^{* * *}$ & $<.001$ & -0.024 & 0.872 \\
\hline \multicolumn{7}{|l|}{ GLOBE Cultural Practices } \\
\hline Institutional Collectivism & $0.248 \dagger$ & 0.164 & 0.045 & 0.802 & $0.220 \dagger$ & 0.218 \\
\hline Ingroup Collectivism & $-0.515 * *$ & 0.002 & $-0.537 * *$ & 0.001 & -0.077 & 0.670 \\
\hline Power Distance & -0.141 & 0.432 & $-0.369 *$ & 0.034 & 0.155 & 0.390 \\
\hline Uncertainty Avoidance & $0.349 *$ & 0.047 & $0.514 * *$ & 0.002 & -0.071 & 0.695 \\
\hline Humane Orientation & -0.063 & 0.728 & -0.050 & 0.783 & -0.011 & 0.952 \\
\hline Performance Orientation & 0.152 & 0.398 & $0.300 \dagger$ & 0.090 & -0.084 & 0.643 \\
\hline Future Orientation & $0.250 \dagger$ & 0.160 & $0.417 *$ & 0.016 & -0.102 & 0.573 \\
\hline Gender Egalitarianism & -0.137 & 0.447 & -0.101 & 0.578 & -0.049 & 0.786 \\
\hline Assertiveness & -0.123 & 0.496 & -0.003 & 0.987 & -0.142 & 0.429 \\
\hline \multicolumn{7}{|l|}{ GLOBE Cultural Values } \\
\hline Institutional Collectivism & $-0.336 \dagger$ & 0.056 & -0.076 & 0.674 & $-0.278 \dagger$ & 0.118 \\
\hline Ingroup Collectivism & 0.084 & 0.642 & -0.179 & 0.320 & $0.234 \dagger$ & 0.190 \\
\hline Power Distance & -0.105 & 0.562 & 0.027 & 0.883 & -0.105 & 0.561 \\
\hline Uncertainty Avoidance & $-0.524 * *$ & 0.002 & $-0.394 *$ & 0.023 & -0.191 & 0.287 \\
\hline Humane Orientation & 0.156 & 0.387 & -0.062 & 0.730 & 0.185 & 0.304 \\
\hline Performance Orientation & 0.178 & 0.321 & -0.066 & 0.714 & $0.221 \dagger$ & 0.215 \\
\hline Future Orientation & -0.094 & 0.602 & $-0.240 \dagger$ & 0.179 & 0.101 & 0.576 \\
\hline Gender Egalitarianism & $0.337 \dagger$ & 0.055 & 0.051 & 0.777 & $0.262 \dagger$ & 0.140 \\
\hline Assertiveness & 0.047 & 0.796 & 0.028 & 0.878 & 0.025 & 0.890 \\
\hline \multicolumn{7}{|c|}{ Schwartz Cultural Orientations } \\
\hline Harmony & 0.199 & 0.201 & -0.031 & 0.845 & $0.207 \dagger$ & 0.184 \\
\hline Mastery & 0.055 & 0.727 & -0.064 & 0.683 & 0.093 & 0.553 \\
\hline Hierarchy & $-0.307 *$ & 0.045 & $-0.248 \dagger$ & 0.109 & -0.098 & 0.530 \\
\hline Egalitarianism & $0.519 * * *$ & $<.001$ & $0.285 \dagger$ & 0.064 & $0.274 \dagger$ & 0.075 \\
\hline Embeddedness & $-0.601 * * *$ & $<.001$ & $-0.277 \dagger$ & 0.072 & $-0.358 *$ & 0.018 \\
\hline Affective Autonomy & $0.580 * * *$ & $<.001$ & $0.390 * *$ & 0.010 & $0.257 \dagger$ & 0.097 \\
\hline Intellectual Autonomy & $0.462 * *$ & 0.002 & $0.259 \dagger$ & 0.094 & $0.244 \dagger$ & 0.115 \\
\hline
\end{tabular}

Note: $* p<.05, * * p<.01, * * * p<.001 ; \dagger r>0.2$; Hofstede $\mathrm{n}=46-47$; GLOBE $\mathrm{n}=33$;

Schwartz $n=43$; in the original Hofstede cultural dimensions, the Individualism-Collectivism dimension is coded such that higher values indicate greater individualism. For the purposes of maintaining consistency and ease of interpretation with other cultural indices, this dimension was reverse coded in this study such that higher values indicated greater collectivism. 
Table 4. Mixed Effects Logistic Modeling for Collectivism on Risk-Aversion

\begin{tabular}{|c|c|c|c|c|c|}
\hline & Base Model & Hofstede & $\begin{array}{l}\text { GLOBE } \\
\text { Practices }\end{array}$ & $\begin{array}{l}\text { GLOBE } \\
\text { Values }\end{array}$ & Schwartz \\
\hline Predictors & OR $(95 \% \mathrm{CI})$ & OR $(95 \% \mathrm{CI})$ & OR $(95 \% \mathrm{CI})$ & OR $(95 \% \mathrm{CI})$ & OR $(95 \% \mathrm{CI})$ \\
\hline Intercept & $\begin{array}{c}6.505 * * * \\
(5.010-8.447)\end{array}$ & $\begin{array}{c}6.599 * * * \\
(5.082-8.570)\end{array}$ & $\begin{array}{c}6.184 * * * \\
(4.525-8.451)\end{array}$ & $\begin{array}{c}6.108 * * * \\
(4.454-8.377)\end{array}$ & $\begin{array}{c}6.201 * * * \\
(4.713-8.158)\end{array}$ \\
\hline Condition & $\begin{array}{c}0.258 * * * \\
(0.226-0.294)\end{array}$ & $\begin{array}{c}0.254 * * * \\
(0.222-0.290)\end{array}$ & $\begin{array}{c}0.258 * * * \\
(0.219-0.303)\end{array}$ & $\begin{array}{c}0.258 * * * \\
(0.219-0.303)\end{array}$ & $\begin{array}{c}0.265 * * * \\
(0.231-0.306)\end{array}$ \\
\hline Age & $\begin{array}{c}1.001 \\
(0.933-1.075)\end{array}$ & $\begin{array}{c}0.973 \\
(0.906-1.046)\end{array}$ & $\begin{array}{c}0.921 \\
(0.848-1.001)\end{array}$ & $\begin{array}{c}0.927 \\
(0.853-1.007)\end{array}$ & $\begin{array}{c}0.976 \\
(0.907-1.051)\end{array}$ \\
\hline Education Attainment & $\begin{array}{c}0.955 \\
(0.892-1.023)\end{array}$ & $\begin{array}{c}0.953 \\
(0.889-1.022)\end{array}$ & $\begin{array}{c}0.980 \\
(0.906-1.061)\end{array}$ & $\begin{array}{c}0.978 \\
(0.903-1.059)\end{array}$ & $\begin{array}{c}0.969 \\
(0.901-1.042)\end{array}$ \\
\hline Gender Female & $\begin{array}{c}1.152 \\
(0.995-1.334)\end{array}$ & $\begin{array}{c}1.177 * \\
(1.012-1.369)\end{array}$ & $\begin{array}{c}1.333 * * \\
(1.113-1.598)\end{array}$ & $\begin{array}{c}1.345 * * \\
(1.122-1.612)\end{array}$ & $\begin{array}{c}1.213 * \\
(1.036-1.420)\end{array}$ \\
\hline Gender Other & $\begin{array}{c}1.339 \\
(0.724-2.476)\end{array}$ & $\begin{array}{c}1.270 \\
(0.665-2.426)\end{array}$ & $\begin{array}{c}1.422 \\
(0.704-2.874)\end{array}$ & $\begin{array}{c}1.444 \\
(0.714-2.919)\end{array}$ & $\begin{array}{c}1.269 \\
(0.660-2.442)\end{array}$ \\
\hline Employment & $\begin{array}{c}0.925 \\
(0.800-1.069)\end{array}$ & $\begin{array}{c}0.913 \\
(0.787-1.059)\end{array}$ & $\begin{array}{c}0.901 \\
(0.756-1.074)\end{array}$ & $\begin{array}{c}0.908 \\
(0.762-1.083)\end{array}$ & $\begin{array}{c}0.917 \\
(0.786-1.070)\end{array}$ \\
\hline Individualism-Collectivism & & $\begin{array}{c}0.823 * * * \\
(0.754-0.899)\end{array}$ & & & \\
\hline Institutional Collectivism & & & $\begin{array}{c}1.076 \\
(0.967-1.196)\end{array}$ & $\begin{array}{c}0.869 * \\
(0.772-0.978)\end{array}$ & \\
\hline Ingroup Collectivism & & & $\begin{array}{c}0.842 * * \\
(0.756-0.937)\end{array}$ & $\begin{array}{c}0.999 \\
(0.889-1.124)\end{array}$ & \\
\hline Embeddedness & & & & & $\begin{array}{c}0.860 * * \\
(0.783-0.945)\end{array}$ \\
\hline Random Effects & & & & & \\
\hline$\sigma 2$ & 3.29 & 3.29 & 3.29 & 3.29 & 3.29 \\
\hline$\tau 00$ & 0.06 Country & 0.03 Country & 0.04 Country & 0.06 Country & 0.04 Country \\
\hline ICC & 0.02 & 0.01 & 0.01 & 0.02 & 0.01 \\
\hline $\mathrm{N}$ & 49 Country & 47 Country & 33 Country & 33 Country & 43 Country \\
\hline Observations & 4063 & 3902 & 2743 & 2743 & 3573 \\
\hline Marginal R2 / Conditional R2 & $0.123 / 0.139$ & $0.136 / 0.145$ & $0.137 / 0.147$ & $0.133 / 0.148$ & $0.125 / 0.136$ \\
\hline
\end{tabular}


Figure 1. Positive Framing Correlation Plots Between Risk Aversion and Collectivism
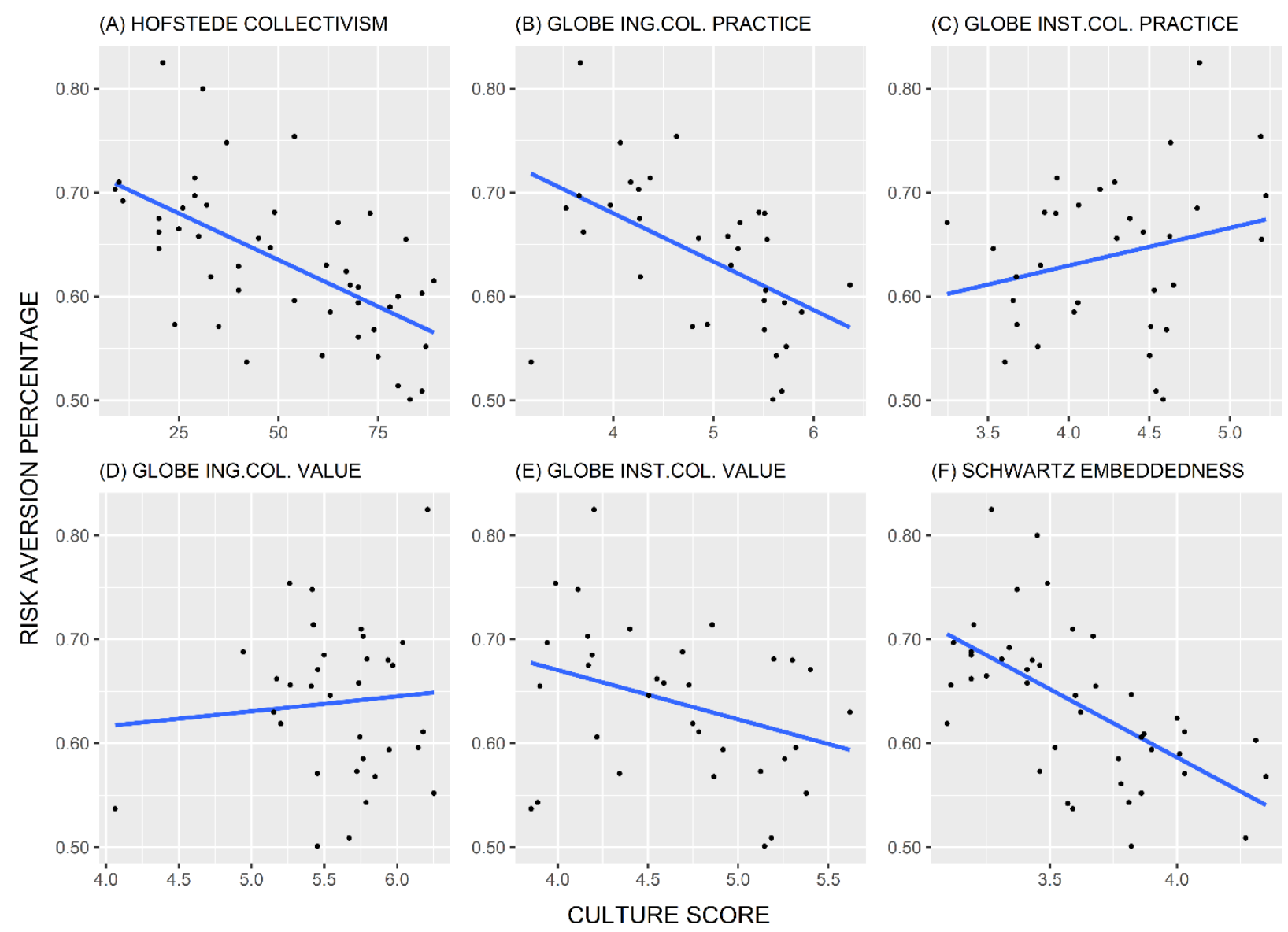
Figure 2. Negative Framing Correlation Plots Between Risk Aversion and Collectivism

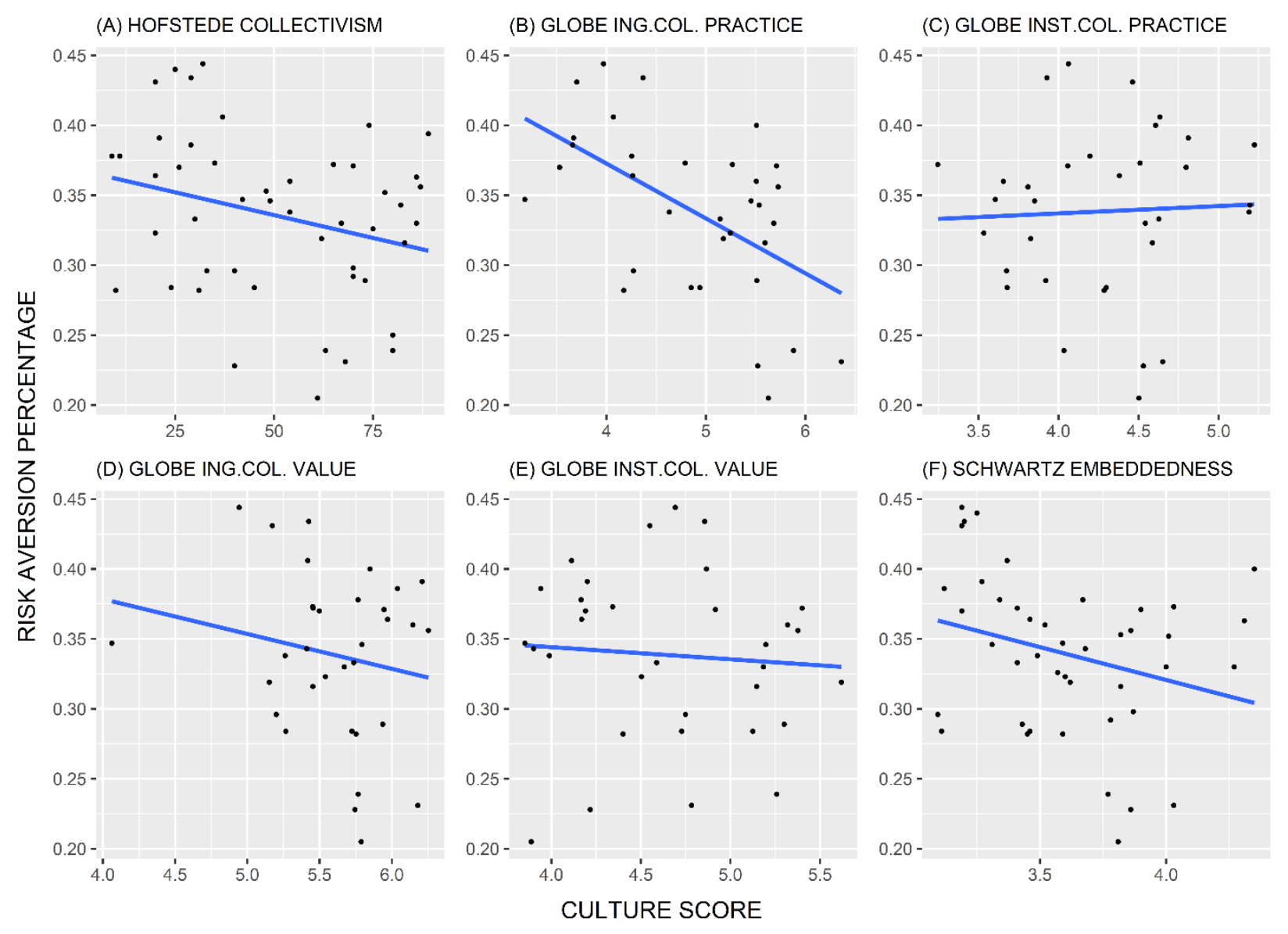


Appendix

2 Table A. Robustness Check of Hofstede Collectivism on Risk-Aversion

\begin{tabular}{|c|c|c|c|c|c|c|}
\hline & M1 & M2 & M3 & M4 & M5 & M6 \\
\hline Predictors & OR $(95 \% \mathrm{CI})$ & OR $(95 \% \mathrm{CI})$ & OR $(95 \% \mathrm{CI})$ & OR $(95 \% \mathrm{CI})$ & OR $(95 \% \mathrm{CI})$ & OR $(95 \% \mathrm{CI})$ \\
\hline Intercept & $\begin{array}{c}6.599 * * * \\
(5.082-8.570)\end{array}$ & $\begin{array}{c}6.595 * * * \\
(5.078-8.564)\end{array}$ & $\begin{array}{c}6.613 * * * \\
(5.094-8.584)\end{array}$ & $\begin{array}{c}6.495 * * * \\
(4.989-8.456)\end{array}$ & $\begin{array}{c}6.569 * * * \\
(5.048-8.549)\end{array}$ & $\begin{array}{c}6.551 * * * \\
(5.041-8.513)\end{array}$ \\
\hline Condition & $\begin{array}{c}0.254 * * * \\
(0.222-0.290)\end{array}$ & $\begin{array}{c}0.254 * * * \\
(0.222-0.290)\end{array}$ & $\begin{array}{c}0.254 * * * \\
(0.222-0.290)\end{array}$ & $\begin{array}{c}0.255 * * * \\
(0.223-0.293)\end{array}$ & $\begin{array}{c}0.255 * * * \\
(0.222-0.292)\end{array}$ & $\begin{array}{c}0.255 * * * \\
(0.222-0.292)\end{array}$ \\
\hline Age & $\begin{array}{c}0.973 \\
(0.906-1.046)\end{array}$ & $\begin{array}{c}0.973 \\
(0.905-1.045)\end{array}$ & $\begin{array}{c}0.972 \\
(0.905-1.044)\end{array}$ & $\begin{array}{c}0.972 \\
(0.904-1.045)\end{array}$ & $\begin{array}{c}0.971 \\
(0.903-1.044)\end{array}$ & $\begin{array}{c}0.966 \\
(0.899-1.039)\end{array}$ \\
\hline Education Attainment & $\begin{array}{c}0.953 \\
(0.889-1.022)\end{array}$ & $\begin{array}{c}0.954 \\
(0.889-1.023)\end{array}$ & $\begin{array}{c}0.954 \\
(0.889-1.023)\end{array}$ & $\begin{array}{c}0.970 \\
(0.904-1.042)\end{array}$ & $\begin{array}{c}0.968 \\
(0.902-1.040)\end{array}$ & $\begin{array}{c}0.967 \\
(0.901-1.039)\end{array}$ \\
\hline Gender Female & $\begin{array}{c}1.177 * \\
(1.012-1.369)\end{array}$ & $\begin{array}{c}1.178 * \\
(1.012-1.370)\end{array}$ & $\begin{array}{c}1.175 * \\
(1.010-1.366)\end{array}$ & $\begin{array}{c}1.200 * \\
(1.030-1.399)\end{array}$ & $\begin{array}{c}1.193 * \\
(1.024-1.390)\end{array}$ & $\begin{array}{c}1.202 * \\
(1.032-1.400)\end{array}$ \\
\hline Gender Male & $\begin{array}{c}1.270 \\
(0.665-2.426)\end{array}$ & $\begin{array}{c}1.275 \\
(0.667-2.436)\end{array}$ & $\begin{array}{c}1.272 \\
(0.666-2.431)\end{array}$ & $\begin{array}{c}1.286 \\
(0.673-2.457)\end{array}$ & $\begin{array}{c}1.272 \\
(0.666-2.428)\end{array}$ & $\begin{array}{c}1.283 \\
(0.672-2.450)\end{array}$ \\
\hline Employment & $\begin{array}{c}0.913 \\
(0.787-1.059)\end{array}$ & $\begin{array}{c}0.913 \\
(0.788-1.059)\end{array}$ & $\begin{array}{c}0.912 \\
(0.787-1.058)\end{array}$ & $\begin{array}{c}0.906 \\
(0.780-1.052)\end{array}$ & $\begin{array}{c}0.904 \\
(0.779-1.050)\end{array}$ & $\begin{array}{c}0.901 \\
(0.776-1.046)\end{array}$ \\
\hline Collectivism & $\begin{array}{c}0.823 * * * \\
(0.754-0.899)\end{array}$ & $\begin{array}{c}0.818 * * * \\
(0.744-0.899)\end{array}$ & $\begin{array}{c}0.862 * \\
(0.766-0.970)\end{array}$ & $\begin{array}{c}0.823 * * * \\
(0.751-0.902)\end{array}$ & $\begin{array}{c}0.853 * * \\
(0.774-0.940)\end{array}$ & $\begin{array}{c}0.874 * \\
(0.779-0.981)\end{array}$ \\
\hline Uncertainty Avoidance & & $\begin{array}{c}1.018 \\
(0.928-1.116)\end{array}$ & & & & $\begin{array}{c}1.042 \\
(0.950-1.142)\end{array}$ \\
\hline Power Distance & & & $\begin{array}{c}0.935 \\
(0.832-1.051)\end{array}$ & & & $\begin{array}{c}0.955 \\
(0.850-1.073)\end{array}$ \\
\hline Long-Term Orientation & & & & $\begin{array}{c}1.035 \\
(0.948-1.130)\end{array}$ & & $\begin{array}{c}1.086 \\
(0.988-1.193)\end{array}$ \\
\hline Indulgence v. Restraint & & & & & $\begin{array}{c}1.079 \\
(0.983-1.185)\end{array}$ & $\begin{array}{c}1.131 * \\
(1.016-1.258)\end{array}$ \\
\hline Random Effects & & & & & & \\
\hline$\sigma 2$ & 3.29 & 3.29 & 3.29 & 3.29 & 3.29 & 3.29 \\
\hline$\tau 00$ & 0.03 Country & 0.03 Country & 0.03 Country & 0.04 Country & 0.03 Country & 0.02 Country \\
\hline $\mathrm{ICC}$ & 0.01 & 0.01 & 0.01 & 0.01 & 0.01 & 0.01 \\
\hline $\mathrm{N}$ & 47 Country & 47 Country & 47 Country & 46 Country & 46 Country & 46 Country \\
\hline Observations & 3902 & 3902 & 3902 & 3820 & 3820 & 3820 \\
\hline Marginal R2 / Conditional R2 & $0.136 / 0.145$ & $0.136 / 0.145$ & $0.136 / 0.145$ & $0.134 / 0.143$ & $0.135 / 0.143$ & $0.137 / 0.143$ \\
\hline
\end{tabular}


Table B. Robustness Check of GLOBE Collectivism Practices on Risk-Aversion

\begin{tabular}{|c|c|c|c|c|c|c|c|c|}
\hline & M1 & M2 & M3 & M4 & M5 & M6 & M7 & M8 \\
\hline Predictors & OR $(95 \% \mathrm{CI})$ & OR $(95 \%$ CI $)$ & OR $(95 \% \mathrm{CI})$ & OR $(95 \% \mathrm{CI})$ & OR $(95 \% \mathrm{CI})$ & OR $(95 \%$ CI $)$ & OR $(95 \% \mathrm{CI})$ & OR $(95 \%$ CI $)$ \\
\hline Intercept & $\begin{array}{c}6.184 * * * \\
(4.525-8.451)\end{array}$ & $\begin{array}{c}6.184 * * * \\
(4.525-8.452)\end{array}$ & $\begin{array}{c}6.131 * * * \\
(4.501-8.350)\end{array}$ & $\begin{array}{c}6.153 * * * \\
(4.512-8.391)\end{array}$ & $\begin{array}{c}6.186 * * * \\
(4.528-8.450)\end{array}$ & $\begin{array}{c}6.187 * * * \\
(4.530-8.451)\end{array}$ & $\begin{array}{c}6.158 * * * \\
(4.515-8.399)\end{array}$ & $\begin{array}{c}6.058 * * * \\
(4.461-8.225)\end{array}$ \\
\hline Condition & $\begin{array}{c}0.258 * * * \\
(0.219-0.303)\end{array}$ & $\begin{array}{c}0.258 * * * \\
(0.219-0.303)\end{array}$ & $\begin{array}{c}0.258 * * * \\
(0.220-0.304)\end{array}$ & $\begin{array}{c}0.258 * * * \\
(0.220-0.303)\end{array}$ & $\begin{array}{c}0.257 * * * \\
(0.219-0.302)\end{array}$ & $\begin{array}{c}0.257 * * * \\
(0.219-0.302)\end{array}$ & $\begin{array}{c}0.257 * * * \\
(0.219-0.302)\end{array}$ & $\begin{array}{c}0.259 * * * \\
(0.220-0.304)\end{array}$ \\
\hline Age & $\begin{array}{c}0.921 \\
(0.848-1.001)\end{array}$ & $\begin{array}{c}0.921 \\
(0.848-1.001)\end{array}$ & $\begin{array}{c}0.916 * \\
(0.843-0.994)\end{array}$ & $\begin{array}{c}0.919 * \\
(0.846-0.998)\end{array}$ & $\begin{array}{c}0.924 \\
(0.850-1.005)\end{array}$ & $\begin{array}{c}0.921 \\
(0.848-1.000)\end{array}$ & $\begin{array}{c}0.916 * \\
(0.843-0.995)\end{array}$ & $\begin{array}{c}0.918 * \\
(0.844-0.998)\end{array}$ \\
\hline Education Attainment & $\begin{array}{c}0.980 \\
(0.906-1.061)\end{array}$ & $\begin{array}{c}0.980 \\
(0.906-1.061)\end{array}$ & $\begin{array}{c}0.984 \\
(0.910-1.065)\end{array}$ & $\begin{array}{c}0.979 \\
(0.905-1.060)\end{array}$ & $\begin{array}{c}0.977 \\
(0.902-1.058)\end{array}$ & $\begin{array}{c}0.978 \\
(0.903-1.058)\end{array}$ & $\begin{array}{c}0.973 \\
(0.899-1.054)\end{array}$ & $\begin{array}{c}0.972 \\
(0.898-1.052)\end{array}$ \\
\hline Gender Female & $\begin{array}{c}1.333 * * \\
(1.113-1.598)\end{array}$ & $\begin{array}{c}1.333 * * \\
(1.112-1.598)\end{array}$ & $\begin{array}{c}1.334 * * \\
(1.113-1.598)\end{array}$ & $\begin{array}{c}1.340 * * \\
(1.118-1.605)\end{array}$ & $\begin{array}{c}1.336 * * \\
(1.115-1.601)\end{array}$ & $\begin{array}{c}1.337 * * \\
(1.116-1.603)\end{array}$ & $\begin{array}{c}1.343 * * \\
(1.121-1.609)\end{array}$ & $\begin{array}{c}1.350 * * \\
(1.127-1.617)\end{array}$ \\
\hline Gender Other & $\begin{array}{c}1.422 \\
(0.704-2.874)\end{array}$ & $\begin{array}{c}1.422 \\
(0.703-2.874)\end{array}$ & $\begin{array}{c}1.416 \\
(0.701-2.862)\end{array}$ & $\begin{array}{c}1.448 \\
(0.716-2.925)\end{array}$ & $\begin{array}{c}1.415 \\
(0.701-2.858)\end{array}$ & $\begin{array}{c}1.424 \\
(0.705-2.877)\end{array}$ & $\begin{array}{c}1.409 \\
(0.698-2.845)\end{array}$ & $\begin{array}{c}1.399 \\
(0.693-2.825)\end{array}$ \\
\hline Employment & $\begin{array}{c}0.901 \\
(0.756-1.074)\end{array}$ & $\begin{array}{c}0.901 \\
(0.756-1.074)\end{array}$ & $\begin{array}{c}0.907 \\
(0.761-1.081)\end{array}$ & $\begin{array}{c}0.901 \\
(0.756-1.073)\end{array}$ & $\begin{array}{c}0.900 \\
(0.755-1.073)\end{array}$ & $\begin{array}{c}0.901 \\
(0.756-1.074)\end{array}$ & $\begin{array}{c}0.902 \\
(0.757-1.074)\end{array}$ & $\begin{array}{c}0.906 \\
(0.761-1.080)\end{array}$ \\
\hline Institutional Collectivism & $\begin{array}{c}1.076 \\
(0.967-1.196)\end{array}$ & $\begin{array}{c}1.075 \\
(0.961-1.203)\end{array}$ & $\begin{array}{c}1.103 * \\
(1.000-1.217)\end{array}$ & $\begin{array}{c}1.157 * \\
(1.024-1.308)\end{array}$ & $\begin{array}{c}1.052 \\
(0.936-1.183)\end{array}$ & $\begin{array}{c}1.069 \\
(0.962-1.187)\end{array}$ & $\begin{array}{c}1.145 * \\
(1.017-1.288)\end{array}$ & $\begin{array}{c}1.156 * \\
(1.019-1.311)\end{array}$ \\
\hline Ingroup Collectivism & $\begin{array}{c}0.842 * * \\
(0.756-0.937)\end{array}$ & $\begin{array}{c}0.843 * \\
(0.728-0.977)\end{array}$ & $\begin{array}{c}0.712 * * * \\
(0.608-0.834)\end{array}$ & $\begin{array}{c}0.854 * * \\
(0.770-0.946)\end{array}$ & $\begin{array}{c}0.851 * * \\
(0.763-0.950)\end{array}$ & $\begin{array}{c}0.837 * * \\
(0.753-0.931)\end{array}$ & $\begin{array}{c}0.825 * * * \\
(0.744-0.916)\end{array}$ & $\begin{array}{c}0.703 * * * \\
(0.578-0.855)\end{array}$ \\
\hline Uncertainty Avoidance & & $\begin{array}{c}1.003 \\
(0.862-1.168)\end{array}$ & & & & & & $\begin{array}{c}0.969 \\
(0.842-1.115)\end{array}$ \\
\hline Power Distance & & & $\begin{array}{c}1.240 * * \\
(1.058-1.453)\end{array}$ & & & & & $\begin{array}{c}1.274 * * \\
(1.069-1.519)\end{array}$ \\
\hline Humane Orientation & & & & $\begin{array}{c}0.882 * \\
(0.781-0.996)\end{array}$ & & & & $\begin{array}{c}0.938 \\
(0.813-1.083)\end{array}$ \\
\hline Performance Orientation & & & & & $\begin{array}{c}1.052 \\
(0.932-1.188)\end{array}$ & & & $\begin{array}{c}1.132 \\
(0.972-1.319)\end{array}$ \\
\hline Gender Egalitarianism & & & & & & $\begin{array}{c}0.947 \\
(0.853-1.052)\end{array}$ & & $\begin{array}{c}1.082 \\
(0.961-1.219)\end{array}$ \\
\hline Assertiveness & & & & & & & $\begin{array}{c}1.129 * \\
(1.001-1.274)\end{array}$ & $\begin{array}{c}1.087 \\
(0.948-1.246)\end{array}$ \\
\hline $\begin{array}{l}\text { Random Effects } \\
\sigma 2\end{array}$ & 3.29 & 3.29 & 3.29 & 3.29 & 3.29 & 3.29 & 3.29 & 3.29 \\
\hline$\tau 00$ & 0.04 Country & 0.04 Country & 0.02 Country & 0.03 Country & 0.04 Country & 0.04 Country & 0.03 Country & 0.01 Country \\
\hline ICC & 0.01 & 0.01 & 0.01 & 0.01 & 0.01 & 0.01 & 0.01 & 0 \\
\hline $\mathrm{N}$ & 33 Country & 33 Country & 33 Country & 33 Country & 33 Country & 33 Country & 33 Country & 33 Country \\
\hline Observations & 2743 & 2743 & 2743 & 2743 & 2743 & 2743 & 2743 & 2743 \\
\hline $\begin{array}{l}\text { Marginal R2 / } \\
\text { Conditional R2 }\end{array}$ & $0.137 / 0.147$ & $0.137 / 0.147$ & $0.141 / 0.147$ & $0.140 / 0.147$ & $0.137 / 0.147$ & $0.138 / 0.147$ & $0.139 / 0.147$ & $0.145 / 0.147$ \\
\hline
\end{tabular}


5 Note: $* p<0.05, * * p<0.01, * * * p<0.001$; M8 yielded high multicollinearity between Ingroup Collectivism and Power Distance (VIF $=4.20-$

6 5.21) but removal of Power Distance from the model did not alter the significance of Ingroup Collectivism. 
Table C. Robustness Check of GLOBE Collectivism Values on Risk-Aversion

\begin{tabular}{|c|c|c|c|c|c|c|c|c|}
\hline & M1 & M2 & M3 & M4 & M5 & M6 & M7 & M8 \\
\hline Predictors & OR $(95 \% \mathrm{CI})$ & OR $(95 \% \mathrm{CI})$ & OR $(95 \% \mathrm{CI})$ & OR $(95 \%$ CI $)$ & OR $(95 \%$ CI $)$ & OR $(95 \%$ CI $)$ & OR $(95 \%$ CI $)$ & OR $(95 \%$ CI $)$ \\
\hline Intercept & $\begin{array}{c}6.108 * * * \\
(4.454-8.377)\end{array}$ & $\begin{array}{c}6.133 * * * \\
(4.482-8.394)\end{array}$ & $\begin{array}{c}6.073 * * * \\
(4.433-8.320)\end{array}$ & $\begin{array}{c}6.063 * * * \\
(4.427-8.302)\end{array}$ & $\begin{array}{c}6.135 * * * \\
(4.492-8.380)\end{array}$ & $\begin{array}{c}6.106 * * * \\
(4.459-8.362)\end{array}$ & $\begin{array}{c}6.108 * * * \\
(4.455-8.376)\end{array}$ & $\begin{array}{c}6.165 * * * \\
(4.519-8.412)\end{array}$ \\
\hline Condition & $\begin{array}{c}0.258 * * * \\
(0.219-0.303)\end{array}$ & $\begin{array}{c}0.258 * * * \\
(0.220-0.303)\end{array}$ & $\begin{array}{c}0.257 * * * \\
(0.219-0.302)\end{array}$ & $\begin{array}{c}0.257 * * * \\
(0.219-0.302)\end{array}$ & $\begin{array}{c}0.257 * * * \\
(0.219-0.302)\end{array}$ & $\begin{array}{c}0.258 * * * \\
(0.220-0.303)\end{array}$ & $\begin{array}{c}0.258 * * * \\
(0.219-0.302)\end{array}$ & $\begin{array}{c}0.257 * * * \\
(0.219-0.302)\end{array}$ \\
\hline Age & $\begin{array}{c}0.927 \\
(0.853-1.007)\end{array}$ & $\begin{array}{c}0.921 \\
(0.847-1.000)\end{array}$ & $\begin{array}{c}0.923 \\
(0.849-1.003)\end{array}$ & $\begin{array}{c}0.923 \\
(0.850-1.003)\end{array}$ & $\begin{array}{c}0.923 \\
(0.849-1.002)\end{array}$ & $\begin{array}{c}0.921 \\
(0.847-1.001)\end{array}$ & $\begin{array}{c}0.927 \\
(0.853-1.008)\end{array}$ & $\begin{array}{c}0.920 * \\
(0.846-0.999)\end{array}$ \\
\hline Education Attainment & $\begin{array}{c}0.978 \\
(0.903-1.059)\end{array}$ & $\begin{array}{c}0.982 \\
(0.907-1.063)\end{array}$ & $\begin{array}{c}0.981 \\
(0.906-1.062)\end{array}$ & $\begin{array}{c}0.978 \\
(0.904-1.059)\end{array}$ & $\begin{array}{c}0.981 \\
(0.906-1.061)\end{array}$ & $\begin{array}{c}0.982 \\
(0.907-1.064)\end{array}$ & $\begin{array}{c}0.979 \\
(0.904-1.060)\end{array}$ & $\begin{array}{c}0.988 \\
(0.912-1.069)\end{array}$ \\
\hline Gender Female & $\begin{array}{c}1.345 * * \\
(1.122-1.612)\end{array}$ & $\begin{array}{c}1.334 * * \\
(1.112-1.599)\end{array}$ & $\begin{array}{c}1.354 * * \\
(1.129-1.623)\end{array}$ & $\begin{array}{c}1.355 * * \\
(1.130-1.625)\end{array}$ & $\begin{array}{c}1.339 * * \\
(1.118-1.605)\end{array}$ & $\begin{array}{c}1.341 * * \\
(1.118-1.607)\end{array}$ & $\begin{array}{c}1.346 * * \\
(1.123-1.614)\end{array}$ & $\begin{array}{c}1.334 * * \\
(1.112-1.601)\end{array}$ \\
\hline Gender Other & $\begin{array}{c}1.444 \\
(0.714-2.919)\end{array}$ & $\begin{array}{c}1.427 \\
(0.706-2.885)\end{array}$ & $\begin{array}{c}1.457 \\
(0.720-2.946)\end{array}$ & $\begin{array}{c}1.444 \\
(0.714-2.918)\end{array}$ & $\begin{array}{c}1.420 \\
(0.702-2.871)\end{array}$ & $\begin{array}{c}1.447 \\
(0.715-2.926)\end{array}$ & $\begin{array}{c}1.439 \\
(0.711-2.910)\end{array}$ & $\begin{array}{c}1.385 \\
(0.684-2.805)\end{array}$ \\
\hline Employment & $\begin{array}{c}0.908 \\
(0.762-1.083)\end{array}$ & $\begin{array}{c}0.908 \\
(0.762-1.083)\end{array}$ & $\begin{array}{c}0.912 \\
(0.765-1.087)\end{array}$ & $\begin{array}{c}0.914 \\
(0.766-1.089)\end{array}$ & $\begin{array}{c}0.908 \\
(0.762-1.082)\end{array}$ & $\begin{array}{c}0.909 \\
(0.763-1.084)\end{array}$ & $\begin{array}{c}0.908 \\
(0.762-1.082)\end{array}$ & $\begin{array}{c}0.906 \\
(0.760-1.079)\end{array}$ \\
\hline Institutional Collectivism & $\begin{array}{c}0.869 * \\
(0.772-0.978)\end{array}$ & $\begin{array}{c}0.915 \\
(0.808-1.035)\end{array}$ & $\begin{array}{c}0.834 * * \\
(0.733-0.950)\end{array}$ & $\begin{array}{c}0.857 * * \\
(0.763-0.961)\end{array}$ & $\begin{array}{c}0.817 * * * \\
(0.727-0.918)\end{array}$ & $\begin{array}{c}0.855 * * \\
(0.761-0.960)\end{array}$ & $\begin{array}{c}0.875 * \\
(0.773-0.990)\end{array}$ & $\begin{array}{c}0.867 \\
(0.736-1.022)\end{array}$ \\
\hline Ingroup Collectivism & $\begin{array}{c}0.999 \\
(0.889-1.124)\end{array}$ & $\begin{array}{c}1.040 \\
(0.923-1.171)\end{array}$ & $\begin{array}{c}0.974 \\
(0.863-1.098)\end{array}$ & $\begin{array}{c}0.959 \\
(0.848-1.086)\end{array}$ & $\begin{array}{c}0.857 * \\
(0.734-0.999)\end{array}$ & $\begin{array}{c}0.977 \\
(0.869-1.099)\end{array}$ & $\begin{array}{c}0.995 \\
(0.883-1.122)\end{array}$ & $\begin{array}{c}0.878 \\
(0.734-1.051)\end{array}$ \\
\hline Uncertainty Avoidance & & $\begin{array}{c}0.879 \\
(0.770-1.004)\end{array}$ & & & & & & $\begin{array}{c}0.910 \\
(0.774-1.070)\end{array}$ \\
\hline Power Distance & & & $\begin{array}{c}0.911 \\
(0.795-1.043)\end{array}$ & & & & & $\begin{array}{c}0.994 \\
(0.791-1.248)\end{array}$ \\
\hline Humane Orientation & & & & $\begin{array}{c}1.107 \\
(0.977-1.254)\end{array}$ & & & & $\begin{array}{c}0.982 \\
(0.777-1.242)\end{array}$ \\
\hline Performance Orientation & & & & & $\begin{array}{c}1.257 * * \\
(1.065-1.484)\end{array}$ & & & $\begin{array}{c}1.248 \\
(0.984-1.582)\end{array}$ \\
\hline Gender Egalitarianism & & & & & & $\begin{array}{c}1.098 \\
(0.975-1.236)\end{array}$ & & $\begin{array}{c}1.004 \\
(0.862-1.170)\end{array}$ \\
\hline Assertiveness & & & & & & & $\begin{array}{c}1.022 \\
(0.905-1.153)\end{array}$ & $\begin{array}{c}1.074 \\
(0.957-1.204)\end{array}$ \\
\hline $\begin{array}{l}\text { Random Effects } \\
\sigma 2\end{array}$ & 3.29 & 3.29 & 3.29 & 3.29 & 3.29 & 3.29 & 3.29 & 3.29 \\
\hline $\begin{array}{l}\tau 00 \\
\text { ICC }\end{array}$ & $\begin{array}{c}0.06 \text { Country } \\
0.02\end{array}$ & $\begin{array}{c}0.05 \text { Country } \\
0.01\end{array}$ & $\begin{array}{c}0.05 \text { Country } \\
0.02\end{array}$ & $\begin{array}{c}0.05 \text { Country } \\
0.01\end{array}$ & $\begin{array}{c}0.04 \text { Country } \\
0.01\end{array}$ & $\begin{array}{c}0.05 \text { Country } \\
0.02\end{array}$ & $\begin{array}{c}0.06 \text { Country } \\
0.02\end{array}$ & $\begin{array}{c}0.03 \text { Country } \\
0.01\end{array}$ \\
\hline $\mathrm{N}$ & 33 Country & 33 Country & 33 Country & 33 Country & 33 Country & 33 Country & 33 Country & 33 Country \\
\hline Observations & 2743 & 2743 & 2743 & 2743 & 2743 & 2743 & 2743 & 2743 \\
\hline $\begin{array}{l}\text { Marginal R2 / } \\
\text { Conditional R2 }\end{array}$ & $0.133 / 0.148$ & $0.136 / 0.148$ & $0.134 / 0.147$ & $0.134 / 0.147$ & $0.138 / 0.147$ & $0.135 / 0.148$ & $0.133 / 0.148$ & $0.140 / 0.147$ \\
\hline
\end{tabular}


$8 \quad$ Note: $* p<0.05, * * p<0.01, * * * p<0.001$; M8 yielded high VIF between Humane Orientation, Performance Orientation, and Gender 9 Egalitarianism $(\mathrm{VIF}=5.29-5.75)$ but removal of these variables did not alter the significance of remaining cultural variables. 
Table D. Robustness Check of Schwartz Embeddedness on Risk-Aversion

\begin{tabular}{|c|c|c|c|c|c|c|c|}
\hline & M1 & M2 & M3 & M4 & M5 & M6 & M7 \\
\hline Predictors & OR $(95 \% \mathrm{CI})$ & OR $(95 \% \mathrm{CI})$ & OR $(95 \% \mathrm{CI})$ & OR $(95 \% \mathrm{CI})$ & OR $(95 \% \mathrm{CI})$ & OR $(95 \% \mathrm{CI})$ & OR $(95 \% \mathrm{CI})$ \\
\hline Intercept & $\begin{array}{c}6.201 * * * \\
(4.713-8.158)\end{array}$ & $\begin{array}{c}6.215 * * * \\
(4.728-8.170)\end{array}$ & $\begin{array}{c}6.185 * * * \\
(4.702-8.137)\end{array}$ & $\begin{array}{c}6.201 * * * \\
(4.714-8.158)\end{array}$ & $\begin{array}{c}6.200 * * * \\
(4.712-8.157)\end{array}$ & $\begin{array}{c}6.187 * * * \\
(4.703-8.139)\end{array}$ & $\begin{array}{c}6.217 * * * \\
(4.728-8.174)\end{array}$ \\
\hline Condition & $\begin{array}{c}0.265 * * * \\
(0.231-0.306)\end{array}$ & $\begin{array}{c}0.265 * * * \\
(0.231-0.305)\end{array}$ & $\begin{array}{c}0.265 * * * \\
(0.231-0.305)\end{array}$ & $\begin{array}{c}0.265 * * * \\
(0.231-0.305)\end{array}$ & $\begin{array}{c}0.266 * * * \\
(0.231-0.306)\end{array}$ & $\begin{array}{c}0.265 * * * \\
(0.231-0.305)\end{array}$ & $\begin{array}{c}0.265 * * * \\
(0.230-0.305)\end{array}$ \\
\hline Age & $\begin{array}{c}0.976 \\
(0.907-1.051)\end{array}$ & $\begin{array}{c}0.977 \\
(0.908-1.052)\end{array}$ & $\begin{array}{c}0.977 \\
(0.908-1.052)\end{array}$ & $\begin{array}{c}0.976 \\
(0.907-1.051)\end{array}$ & $\begin{array}{c}0.976 \\
(0.907-1.051)\end{array}$ & $\begin{array}{c}0.978 \\
(0.908-1.053)\end{array}$ & $\begin{array}{c}0.980 \\
(0.910-1.055)\end{array}$ \\
\hline Education Attainment & $\begin{array}{c}0.969 \\
(0.901-1.042)\end{array}$ & $\begin{array}{c}0.967 \\
(0.899-1.040)\end{array}$ & $\begin{array}{c}0.967 \\
(0.900-1.040)\end{array}$ & $\begin{array}{c}0.969 \\
(0.901-1.042)\end{array}$ & $\begin{array}{c}0.969 \\
(0.901-1.042)\end{array}$ & $\begin{array}{c}0.967 \\
(0.899-1.040)\end{array}$ & $\begin{array}{c}0.966 \\
(0.898-1.039)\end{array}$ \\
\hline Gender Female & $\begin{array}{c}1.213 * \\
(1.036-1.420)\end{array}$ & $\begin{array}{c}1.211 * \\
(1.034-1.418)\end{array}$ & $\begin{array}{c}1.216 * \\
(1.038-1.424)\end{array}$ & $\begin{array}{c}1.213 * \\
(1.036-1.420)\end{array}$ & $\begin{array}{c}1.213 * \\
(1.036-1.420)\end{array}$ & $\begin{array}{c}1.215 * \\
(1.038-1.423)\end{array}$ & $\begin{array}{c}1.212 * \\
(1.035-1.420)\end{array}$ \\
\hline Gender Other & $\begin{array}{c}1.269 \\
(0.660-2.442)\end{array}$ & $\begin{array}{c}1.256 \\
(0.653-2.416)\end{array}$ & $\begin{array}{c}1.267 \\
(0.659-2.438)\end{array}$ & $\begin{array}{c}1.270 \\
(0.660-2.443)\end{array}$ & $\begin{array}{c}1.268 \\
(0.659-2.440)\end{array}$ & $\begin{array}{c}1.269 \\
(0.659-2.442)\end{array}$ & $\begin{array}{c}1.254 \\
(0.652-2.412)\end{array}$ \\
\hline Employment & $\begin{array}{c}0.917 \\
(0.786-1.070)\end{array}$ & $\begin{array}{c}0.916 \\
(0.785-1.068)\end{array}$ & $\begin{array}{c}0.919 \\
(0.788-1.071)\end{array}$ & $\begin{array}{c}0.917 \\
(0.786-1.070)\end{array}$ & $\begin{array}{c}0.917 \\
(0.786-1.069)\end{array}$ & $\begin{array}{c}0.919 \\
(0.788-1.072)\end{array}$ & $\begin{array}{c}0.917 \\
(0.786-1.069)\end{array}$ \\
\hline Embeddedness & $\begin{array}{c}0.860 * * \\
(0.783-0.945)\end{array}$ & $\begin{array}{c}0.909 \\
(0.719-1.149)\end{array}$ & $\begin{array}{c}0.845 * * \\
(0.757-0.943)\end{array}$ & $\begin{array}{c}0.860 * * \\
(0.783-0.945)\end{array}$ & $\begin{array}{c}0.857 * \\
(0.752-0.976)\end{array}$ & $\begin{array}{c}0.851 * \\
(0.744-0.972)\end{array}$ & \\
\hline Affective Autonomy & & $\begin{array}{c}1.112 \\
(0.949-1.303)\end{array}$ & & & & & $\begin{array}{c}1.151 * \\
(1.005-1.318)\end{array}$ \\
\hline Intellectual Autonomy & & $\begin{array}{c}0.963 \\
(0.804-1.154)\end{array}$ & & & & & $\begin{array}{c}1.010 \\
(0.872-1.171)\end{array}$ \\
\hline Hierarchy & & & $\begin{array}{c}1.036 \\
(0.928-1.156)\end{array}$ & & & $\begin{array}{c}1.039 \\
(0.919-1.175)\end{array}$ & $\begin{array}{c}1.016 \\
(0.897-1.150)\end{array}$ \\
\hline Mastery & & & & $\begin{array}{c}1.011 \\
(0.922-1.110)\end{array}$ & & $\begin{array}{c}1.003 \\
(0.910-1.106)\end{array}$ & $\begin{array}{c}0.995 \\
(0.899-1.102)\end{array}$ \\
\hline Egalitarianism & & & & & $\begin{array}{c}0.994 \\
(0.874-1.130)\end{array}$ & $\begin{array}{c}1.012 \\
(0.881-1.163)\end{array}$ & $\begin{array}{c}1.032 \\
(0.909-1.172)\end{array}$ \\
\hline $\begin{array}{l}\text { Ran } \\
\sigma 2\end{array}$ & 3.29 & 3.29 & 3.29 & 3.29 & 3.29 & 3.29 & 3.29 \\
\hline$\tau 00$ & 0.04 Country & 0.04 Country & 0.04 Country & 0.04 Country & 0.04 Country & 0.04 Country & 0.04 Country \\
\hline ICC & & & 0.01 & 0.01 & 0.01 & 0.01 & 0.01 \\
\hline $\mathrm{N}$ & 43 Country & 43 Country & 43 Country & 43 Country & 43 Country & 43 Country & 43 Country \\
\hline Obser & 3573 & 3573 & 3573 & 3573 & 3573 & 3573 & 3573 \\
\hline Marginal R2 / Conditional R2 & $0.125 / 0.136$ & $0.126 / 0.136$ & $0.126 / 0.136$ & $0.125 / 0.136$ & $0.125 / 0.136$ & $0.126 / 0.136$ & $0.126 / 0.136$ \\
\hline
\end{tabular}


11 Note: $* p<0.05, * * p<0.01, * * * p<0.001 ; \mathrm{M} 2$ model yielded high multicollinearity between Embeddedness and the two Autonomy variables

$12 \quad(\mathrm{VIF}=3.08-6.69)$. M6-7 examined Embeddedness and Autonomy independently to handle multicollinearity. 